\title{
Authority Of The Police In The Eradication Of Criminal Acts Of Terorism According To Law No. 15 Of 2003
}

\section{Melky Sidhek Gultom}

Sumatera University Faculty Of Law. E-mail: melkysidhek@gmail.com

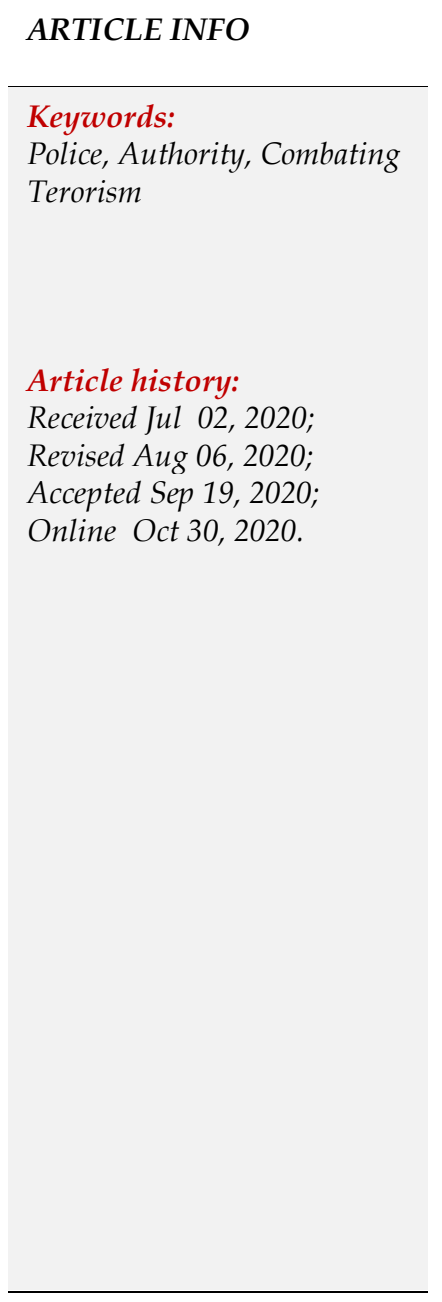

\begin{abstract}
Terrorism is a terrible threat to every country in the world, destroying state stability, security functions, socio-cultural, economic, political and can even shake various religious parties. As a state of law, Indonesia has an obligation to protect the rights of its citizens. Through Law Number 15 of 2003 concerning the Eradication of Criminal Acts of Terrorism and Law Number 2 of 2002 concerning the Police, terrorists must be eradicated to their roots to create security, peace and social welfare for the community. For this reason, the authority of the Police in eradicating criminal acts of terrorism is to establish the Special Datasemen 88 Anti-Terror as a special elite force to deal with terrorist acts and their eradication. The problems discussed in this thesis are: First, how is the regulation of criminal acts of terrorism according to Law Number 15 of 2003 concerning the eradication of criminal acts of terrorism? Second, how is the authority of the Police in eradicating criminal acts of terrorism, the method used in this thesis is the normative juridical approach, the data source used is secondary data through library research data collection tools and through qualitative data. The conclusion in this thesis, that the authority of the Police in eradicating criminal acts of terrorism refers to the various efforts taken, the application of legal regulations and sanctions against terrorist actors, as well as implementing penal and non-penal policies, UUPTPT applies retroactive law enforcement to cases cases that have passed before the emergence of the PTPT Law which regulates it, the authority of the Police to provide protection, protection, and law enforcement for the community and involves the role of the Special Detachment 88 Anti-Terror as the forefront in carrying out prosecutions and arrests. It is recommended for the National Police to carry out surveillance of urban and rural residents for the role of the Community Police (Polmas) which is very important as an early detection of the development of the local community.
\end{abstract}

This is an open access article under the CC BY-NC license.

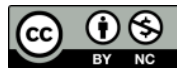

\section{Introduction}

Terrorism is attacks coordinated which aims to arouse feelings of terror against a group of people Observing the handling of cases of criminal acts of terrorism that are happening today, linked according to Law Number 15 of 2003 concerning terrorism, the role of the police to prevent and eradicate terrorism syndicates that have spread throughout the world must be handled vigilantly and seriously .Terrorism, not only threatens developed countries such as the United States, Britain and Australia, but also occurs in developing countries such as Indonesia. This is the same as what Nasir Abas said in his book entitled "Eradicating Terrorism, Hunting Noordin M. Top", namely "terrorism is not dead in Indonesia. 
Indonesia. The pattern of modern terrorism gave rise to a new phenomenon called the phantom cell network, leaderless resistance (without a leader) and the lone wolver (lone wolf). ${ }^{7}$ The concept of terrorism ghost cell network is that the relationship between groups is carried out in a very secret way, there are no group ties, the structure is not clear, but the ideological goals are the same. The concept of "leaderless" terrorism can be said to be a motivational theory, where the spiritual leader only motivates people who are considered sincere to become martyrs to determine and attack their own targets. These figures will be worked out in a relationship pattern that seems so religious, then facilitated to get logistical support to carry out their actions.

Meanwhile, "lone wolves" are actors who have been motivated and are able to plan and execute acts of terrorism independently. In this case, the status of the actor or organization is not very important, the most important thing is that terrorism continues, more and more cadres get more cadres and attacks continue even though on a small scale it is not surprising. when responding to the actions of the "lone wolves" lately, it would be so easy for the behind-thescenes actor to say he wasn't involved.

After the new pattern of terrorism, the next is known as the hybrid terrorism pattern. Some experts make the hybrid terrorism pattern part of a new pattern and others place it in a separate trend. In the Merriam-Wesbter dictionary, hybrid means "offspring, variety, species or breed of two heterogeneous cultures, origins or composites". The term hybrid terrorism that is most widely agreed upon is Boaz Ganor's version, namely "a terrorist organization that carries out its actions through political contests and violence".

In this context, terrorists will use operational concepts in multi-character forms in the form of legitimate political organizational instruments, but can motivate violence through "phantom cell networks", pretending to build educational and welfare media, buy sympathy and recruit with appocalypstic understanding (sooner or later). doomsday will come) and channel the aspirations of political resistance and indoctrination through the media. The operating model is also called hybrid operation, which I term as a cross-marriage of the old and new patterns, to produce the most optimal results to achieve the goal.

A series of bomb tragedies that occurred in the past and the factors that influence the existence of these terrorist syndicates need to be watched out for and sought solutions by the world government, especially in Indonesia. The proof is that the terrorist syndicate was able to shake the superpower of the United States of America until it broke through the World Trade Center building in the United States, known as the 2001 World Trade Center Tragedy. Thousands of people died, traumatized, injured and disabled for life in an instant.

In Indonesia, the entry of terrorists began to refer to threats in public places such as hotels, malls and crowded places as well as threats through telecommunications media that made residents panic so many people wondered whether the Indonesian state was able to handle it and was still safe.

Facts prove that terrorism is "not dead" in the territory of the Unitary State of the Republic of Indonesia (NKRI), there have been several terrorist bombing incidents such as: at the Istiqlal Mosque on April 19, 1999, the Christmas Eve Bombing on December 24, 2000, the Bombing at the Jakarta Stock Exchange last month. September 2000, the hostage-taking and occupation of the Mobil Oil Company by the Free Aceh Movement in 2000, the Bali Bombing I on October 12, 2002 at the Sari Club and Peddy's Club, Kuta Bali, the bombing at JW. Marriot in 2003, bombing in front of the Australian Embassy in 2004, Bali II bombing in 2005, and a terrorist training group in Nangro Aceh Darussalam. Until then the Special Detachment (Densus) 88 Anti-Terror Police shot dead Noordin M. Top in Temanggung on August 8, 2009.11 Which continued with the robbery of CIMB Niaga Bank in Medan, North Sumatra on August 18, 2010, where the 
perpetrators of the bank robbery were related to a terrorist organization network in terms of financing terrorism operations.

Based on a series of bombings and terrorist acts that occurred in the territory of the Republic of Indonesia, it has resulted in the loss of life regardless of the victim's ethnicity, religion, race, nationality. All of these are targets, because in general terrorists detonate the bombs regardless of who is the victim in crowded places and even bombs are detonated in mosques or churches when carrying out worship or prayers, as happened on Friday at the City Resort Police Headquarters. Cirebon, West Java on April 15, 2011.

Terrorism has had wide dimensions and networks related to various aspects of life that transcend national boundaries and can be said to be a crime involving the international community. Currently, terrorism does not only make political life its target as it first appeared, but has added and destroyed various aspects of human life, such as the decline in economic activity and the disruption of the life and culture of a civilized society so that it is classified as one of the eight trans national crimes.

Terrorism is a crime against humanity that poses a threat to all nations and is the enemy of all religious adherents of this world. Today, in its development, terrorism has built an organization and has a global network where terrorist groups that play a role and spread in various countries have been controlled by an international terrorism network and have had a way and system of working mechanism relationships between one another both in terms of operational infrastructure as well as in supporting infrastructure.

In the view of Indonesian law, terrorism is one of the main and real problems and threats, both to the implementation of the Constitution's mandate and to the welfare of the Indonesian people, including protecting the entire Indonesian homeland and promoting public welfare. Therefore, acts of terrorism should be considered as a threat to national life and welfare which will affect national security and stability.

\section{Method}

The approach method used in this research is normative juridical, namely Legal Research conducted by examining library materials or secondary data, in the form of positive law and how it is applied in practice in Indonesia.

Data collection is done by studying documents relevant to this research in the library and identifying existing data or cases. The data obtained through the literature research will then be sorted in order to obtain articles in the PTPT Law which contain legal rules which are then linked to the problems being faced and systematized.

The data analysis in this study was carried out qualitatively, namely the selection of theories, principles, norms, doctrines, and articles in the most important laws that are relevant to the problem. Then make a systematic from the data so that it will produce a certain classification according to the problems discussed. Qualitatively analyzed data will be presented in the form of a systematic description by explaining the relationship between various types of data, then all data are selected and processed and then stated deductively, to arrive at conclusions, so that the main problems studied in this study can be answered.

\section{Analysis And Results}

3.1 Crime Of Terorism According To Law Number 15 Year 2003 
In terms of efforts to prevent terrorist attacks from occurring in recent tragedies, the government issued Regulation Number 1 of 2002 which was later promulgated into Law Number 15 of 2003 concerning the Eradication of Criminal Acts of Terrorism (UUPTPT). International terrorism is an organized crime, so the Indonesian government increases vigilance in maintaining the integrity of the Unitary State of the Republic of Indonesia. ${ }^{37}$ The General Chairperson of the Nahdlatul Ulama Executive Board (PBNU) KH Hasyim Muzadi reminded the dangers of terrorism that still threaten Indonesia, even though the terrorists have been arrested. Related to that, his party requested that terrorism should not only be considered the form of terror alone, with a security approach, but also its ism or ideology must be resolved. Terrorism does not always arise on the basis of religion. Fundamentalism or liberalism will not be effective in eliminating radicalism. Terrorism is not Islam and Islam is not terrorism. The emergence of terrorism in the Muslims is a misunderstanding of the nature of the teachings of the religion itself. So do not see the completeness of Islam comprehensively, but partial understanding. This misunderstanding later developed into the abuse of religion. ${ }^{39}$ Regarding terrorism, in fact many factors originate from non-religious origins. But using religious people and using religious themes.

According to former Head of the State Intelligence Agency (BIN) Hendropriyono in a seminar entitled 'Reformulation of NU's Views on Terrorism' at the PBNU Building, Jakarta, Thursday $(4 / 3 / 2010)$, addressing the problem of terrorism requires serious handling. One of them is the Intelligence Bill, which regulates how to empower terrorists. In addition, acts of terrorism that occur because of the absence of a national fortress that is important to ward off all acts of radicalism. We all hope that the problem of terrorism in Indonesia will be resolved soon. However, all elements of the nation and security forces remain vigilant against the threat of terrorism. Especially aware that terrorism is still around us.

The Indonesian government is aware of the dangers of acts of terrorism which has become an international issue and other countries such as Australia and the United States are so focused on efforts to combat terrorism, ${ }^{41}$ therefore the need for an understanding of terrorism according to UUPTPT.

The consideration section in the PTPT Law considers that terrorism has an impact on eliminating lives regardless of the victim and causing fear for the community as a whole or the loss of independence for every human being, as well as loss of property, therefore eradication steps need to be implemented so that the PTPT Law is absolutely necessary. The aim is to make terrorism a criminal act in Indonesia, and terrorism is categorized as a special crime that must be completely eradicated from the roots.

Before discussing further the regulation of criminal acts according to Law No. 15 of 2003 concerning criminal acts of terrorism, the author will explain a series of crimes in general. Law Number 1 of 1946 concerning the Criminal Code (KUHP) is a product of Indonesian law whose contents were made by the Dutch Colonial Government, so that the existing Criminal Code is nothing but the result of translation by several Indonesian scholars.

\subsection{Subjects of Criminal Acts and Elements in Law Number 15 Year 2003}

The subject of the criminal act of terrorism listed in the PTPT Law as in the criminal law was initially only human as a natural person, but in its development legal entities or corporations can also become legal subjects. In this regard, the provisions of Article 1 number 2 of the PTPT Law are stated, "every person is an individual, a group of people, whether civilian, military, or police, who are individually responsible, or corporately".

Based on the provisions of Article 1 point 2 above, it can be understood that the subject of the criminal act of terrorism is not only limited to humans as individuals, but also includes legal entities or corporations. This means that the PTPT Law has carried out extensive interpretation 
of legal subjects. In addition, the UUPTPT also contains regulations regarding the concept of participation. This can be seen in Article 13 of the Company Law, as follows:

Anyone who intentionally provides assistance or facilities to perpetrators of criminal acts of terrorism, by:

a. Giving or lending money or goods or other assets to perpetrators of criminal acts of terrorism;

b. Hiding the perpetrators of criminal acts of terrorism; and or

c. Hiding information about criminal acts of terrorism.

Article 13 of the PTPT Law above, regulates penalties for criminal acts in the event of In the Second Book of the Criminal Code, "Crime", it is clarified that the elements of criminal acts related to the crime of terrorism are:

Element objective (deed) which done party terrorist for launch the action with an "action" is by example:

a. Crimes against state security are regulated in article 104, article 107, article 107a, article 107 b, article 107e, article 107f, article 108, article 110, article 111, article 123, article 124 of the Criminal Code.

b. Crimes that endanger public safety for people or goods are regulated in article 187, article 187 bis, article 191, article 192, article 198, article 200 of the Criminal Code.

c. Crimes against life are regulated in article 338, article 340 of the Criminal Code.

Meanwhile, in Law Number 15 of 2003 concerning the criminal act of terrorism, an example of an article that uses the method of formulating a crime by describing its elements without providing qualifications for the crime is Article 6 of the PTPT Law.

Participation in the form of assistance (medeplichtigheid) in committing a criminal act of terrorism. Article 14 UUPTPT reads: "Everyone who plans and/or mobilizes another person to commit a criminal act of terrorism as referred to in Article 6, Article 7, Article 8, Article 9, Article 10, Article 11, and Article 12 shall be sentenced to death or life imprisonment" .

\subsection{Sanctions for Criminal Acts of Terrorism according to Law Number 15 of 2003 concerning Terrorism}

Regarding the threat of sanctions for perpetrators who "participate" or "participate" in the provisions of Article 9 which reads: "Every person who unlawfully imports into Indonesia, makes, receives, tries to obtain, surrenders or tries to surrender, controls, carries, has in his possession, keeps, transports, hides, uses, or releases to and/or from Indonesia a firearm. , ammunition, or any explosives and other dangerous materials with the intention of committing a criminal act of terrorism, shall be punished with death penalty or life imprisonment or imprisonment for a minimum of 3 (three) years and a maximum of 20 (twenty) years.".

Article 11 "Shared with imprisonment for a minimum of 3 (three) years and a maximum of 20 (twenty) years, any person who intentionally provides or collects funds with the aim of being used or knowingly will be used partly or wholly to commit a criminal act of terrorism as referred to in paragraph (1). in Article 6, Article 7, Article 8, Article 9, and Article 10".

Article 12 "Criminalized for committing a criminal act of terrorism with a minimum imprisonment of 3 (three) years and a maximum of 20 (twenty) years, any person who intentionally provides or collects assets with the purpose of being used or ought to know in part or in whole to:

a The act of unlawfully receiving, possessing, using, surrendering, altering, disposing of nuclear materials, chemical weapons, biological weapons, radiology, microorganisms, 
radioactivity or its components which result in or may result in death or serious injury or inflict damage to property;

b. Steal or seize nuclear materials, chemical weapons, biological weapons, radiology, microorganisms, radioactivity or their components;

c. Embezzlement or illegally obtaining nuclear materials, chemical weapons, biological weapons, radiology, microorganisms, radioactivity or their components;

d. Requesting nuclear materials, chemical weapons, biological weapons, radiology, microorganisms, radioactivity or their components by force or threat of violence or by any form of intimidation

e. Threaten:

1) Using nuclear materials, chemical weapons, biological weapons, radiology, microorganisms, radioactivity or their components to cause death or serious injury or property damage; or

2) Committing a criminal act as referred to in letter $b$ with the aim of forcing other people, international organizations, or other countries to do or not to do something.

f. Attempting to commit a criminal act as referred to in letter a, letter b, letter c; and

g. Participate in committing the criminal acts as referred to in letters a to $\mathrm{f}^{\prime \prime}$.

\subsection{Authority according to KUHAP}

The Criminal Procedure Code (KUHAP) applies the Criminal Justice System, which means: The system in a society to tackle the problem of crime.

The implementation of criminal justice is the mechanism by which law enforcement officers work starting from the process of investigation and investigation, arrest and detention, prosecution and examination in court, as well as the implementation of court decisions. Or in other words the work of the police, prosecutors, judges, and correctional officers, which also means the process or operation of the criminal procedure law.

\section{a. Police Function as Investigation}

The police are law enforcement officers with functions as "investigators" and "investigators". In article 1 paragraph 4 of the Criminal Procedure Code, the investigator is a state police official of the Republic of Indonesia who is authorized by law to conduct an investigation. What is meant by an investigation in the article is a series of investigative actions to seek and find an event that is suspected to be a criminal act in order to determine whether or not an investigation can be carried out according to the method regulated in the Criminal Procedure Code.

Investigation is not a separate function that is separate from investigation, but is only one of the methods or methods of the investigative function that precedes other actions, namely prosecution in the form of arrest, detention, search, confiscation, examination of letters, summons for examination actions, completion and submission of case files to prosecutors. General.

\section{b. Police function as investigator}

Article 1 paragraph 1 of the Criminal Procedure Code states that "Investigators are state police officers of the Republic of Indonesia or certain civil servants who are given special authority by law to conduct investigations". Further arrangements regarding investigators are contained in Article 2 of Government Regulation No. 27 of 1983, stipulated the terms for the rank and appointment of investigators, namely:

1) The State Police of the Republic of Indonesia has the rank of at least Second Lieutenant Police Assistant;

2) Certain Civil Servant Officials with a rank of at least Level 1 Junior Registrar (class II/b) or 
the equivalent;

3) If there is no investigating officer in a Police Sector, then the Police Sector Commander with the rank of NCO is under the Assistant to the Police Second Lieutenant, because his position is an investigator;

c. First Action on the Scene

Actions taken by investigators at the scene of the case, which are needed to:

1) Save the life of the victim

2) Arrest the perpetrators who are still in the vicinity of the crime scene (TKP)

3) Closing the scene to anyone in order to maintain the condition of the scene so that it remains as it was at the time of the crime. This is very necessary for the purposes of the investigation so that the incident becomes clear and the truth of the crime can be found.

4) Finding, rescuing, collecting, and retrieving evidence that can assist investigators in obtaining clues about the identity of the perpetrator, the methods and tools used by the perpetrator. Everything oni is needed to overcome the possibility of the perpetrator providing an alibi or lie that the perpetrator can reveal at the time the investigation is carried out on the perpetrator

\section{d. Arrest}

Arrest is the authority of the investigator for the purposes of the investigation. Arrest is necessary so that the perpetrators of criminal acts do not escape or eliminate evidence that can incriminate themselves. Although the arrest is the authority of the investigator, it does not mean that the investigator can arrest someone at will. Article 17 of the Criminal Procedure Code stipulates the conditions for making an arrest. The condition is that there is sufficient preliminary evidence that a person who is strongly suspected of having committed a criminal act can be arrested. This is necessary to avoid mistakes in the arrest.

Arrest is a forced effort that is directly related to human rights, namely the deprivation of freedom. Therefore, the Criminal Procedure Code provides clear limits on the conditions for an arrest to be made. Article 1 number 20 states that an arrest is an act of an investigator in the form of a temporary restraint on the freedom of a suspect or defendant if there is sufficient evidence for the purposes of investigation or prosecution and/or trial in matters and according to the method regulated by this law.

Investigators or investigators assigned by investigators must bring an arrest warrant at the time of making an arrest. This is regulated in Article 18 paragraph (1) of the Criminal Procedure Code which states, the implementation of the task of arresting is carried out by officers of the Indonesian National Police by showing a letter of assignment and giving the suspect an arrest warrant that includes the identity of the suspect and states the reason for the arrest as well as a brief description of the suspected crime case. and where it was checked.

1) Detention

Detention is a form of deprivation of one's freedom of movement. So detention is an investigator's authority which is very contrary to human rights. Therefore, detention is a form of effort to reveal a criminal act and in this case the investigator must be really careful to detain someone.Therefore, detention should be carried out if necessary. Mistakes in detention can have fatal consequences for detention. In the Criminal Procedure Code, it is regulated about compensation in article 95 in addition to being able to conduct pretrial.

2) For the purposes of the investigation, the investigator or assistant investigator on the orders of the investigator is authorized to make detention. Regarding the size of the interest of the investigation, it is basically determined by the fact that the need for an investigative examination itself is objective. Depending on the level of effort needed by the investigator to complete the investigation completely and completely. When the investigation is complete, detention is no longer necessary 
3) Detention carried out by the public prosecutor, aimed at the interest of the prosecution Detention carried out by the judiciary is intended for the purpose of examination at the court level. The judge has the authority to make detention with a determination based on whether or not the detention is carried out in accordance with the interests of the examination in court.

\section{e. Search}

In terms of law and legislation as explained in Article 1 number 17 of the Criminal Procedure Code, house search is the action of an investigator to enter a residential house and other closed places to carry out investigations and or confiscation and or arrests in the case and according to the method regulated in the law. law. A body search is regulated in Article 1 point 18 of the Criminal Procedure Code which reads that a body search is an investigator's act to carry out an examination of the suspect's body and or clothing to look for objects that are strongly suspected to be on his body or brought along for confiscation.

From a legal point of view, a search is an investigator's act that is justified by law to enter and carry out an inspection at a person's residence or to carry out an examination of a person's body and clothes. In fact, it does not only carry out examinations, but it is also biased at the same time to make arrests and confiscations. In terms of human rights, the investigator's actions have violated a person's human rights for the sake of law enforcement and maintaining public order.

Investigators have the authority to search, but they cannot be carried out arbitrarily. The investigator must first seek permission from the Head of the District Court, or in circumstances of necessity the investigator may conduct a search without a permit, but after the search has been carried out, it is the investigator's obligation to report the search to the Chairman of the District Court.

\section{f. Foreclosure}

The definition of confiscation is regulated in Article 1 point 16, namely: "Confiscation is a series of actions by an investigator to take over and or keep under his control movable or immovable objects, tangible or intangible, for the purpose of proof in investigation, prosecution and trial." Article 38 of the Criminal Procedure Code states: "Confiscation can only be carried out by investigators with a permit from the Head of the local District Court." This affirmation is intended to enforce legal certainty. In order to avoid confusion as happened in the past where the Police and the public prosecutor both have the authority to confiscate, as a result of their status, they both have the authority to carry out investigations.

If an application for confiscation is submitted by an investigator if it is not approved by the Head of the local District Court, the investigator cannot carry out a confiscation. This is confirmed in Article 38 paragraph 1 of the Criminal Procedure Code. And in paragraph 2 it is stated that investigators can only confiscate movable objects. If the confiscation is carried out at a time of coercion or in a state of being caught red-handed, then after the confiscation the investigator must notify the confiscation to the Head of the local Court for approval.

\section{g. Mail Check}

Article 47 of the Criminal Procedure Code states that investigators have the right to open, examine, and confiscate other letters sent through post and telecommunications offices, telecommunications or transportation agencies or companies. Another letter in Article 47 of the Criminal Procedure Code is a letter that has a relationship with a criminal act or case that is being examined, but the relationship is not direct, but is expected to provide instructions for the examination of the case.

To conduct a letter examination, the investigator must request special permission from the Head of the local District Court. With this permit, investigators can open, examine, and even 
confiscate letters suspected of being items that can make light of a criminal act. If the letter has been checked and will be returned to the sending service, the investigator must close the letter neatly. And must be affixed with a stamp that reads "has been opened by investigators". And the stamp was affixed with the date and the investigator's mark as well as the identity of the investigator.

\subsection{Authority under the Police Act}

In a free sense, authority is the right of an individual to take an action with certain limits and is recognized by other individuals in a certain group. While talking about sources of authority, there are 3 (three) sources of authority, namely:

a. Sources of Attribution, namely the granting of authority to certain state bodies or institutions/officials, both by the makers of the Constitution and the legislators. For example: Attribution of the powers of the president and the DPR to form laws.

b. Source of Delegation, namely the handover or delegation of authority from other State administrative official bodies / institutions with the consequence of shifting responsibility to the recipient of the delegation. For example: Implementation of DPRD approval regarding the approval of candidates for deputy regional heads.

c. The source of the Mandate, namely the delegation of authority and responsibility is still held by the person who gave the mandate. For example: The responsibility for making decisions by the minister is mandated to his subordinates.

From these three sources, it is a formal source of authority, while in applications in social life there is also an informal authority owned by a person for various reasons such as : Charisma, wealth, intelligence, or cunning.

\subsection{Authority under the Terrorism Act}

In Law Number 15 of 2003 concerning Criminal Acts of Terrorism, the Special Anti-Terror Datasemen 88 is part of the police which has the authority to act as "investigators" or "investigators" for criminal acts of terrorism. The rest, the legal process is delegated to the District Court based on the provisions of the Criminal Procedure Code (KUHAP).

Determining an act is said to be a criminal act of terrorism is if the act has fulfilled an acthas fulfilled the elements of a criminal act as contained in the regulation of criminal acts of terrorism. ${ }^{124}$ Thus, if an act has fulfilled the elements of the articles in the regulation, then someone has committed a criminal act of terrorism. How the elements or formulation of a criminal act are fulfilled so that a person can be convicted, it is necessary to prove it through the Criminal Procedure Code.

The process of proving the guilt of the perpetrators of criminal acts of terrorism begins in the investigation, investigation, prosecution, and examination in court. Article 25 paragraph 1 of Law Number 15 of 2003 concerning the Crime of Terrorism affirms that: "Investigations, prosecutions, and examinations before courts in cases of criminal acts of terrorism are carried out based on the applicable procedural law, unless otherwise provided for in this Law".

\section{Conclusion}

The regulation of criminal acts of terrorism in the PTPT Law excludes the principle of legality (article 1 paragraph 1 of the Criminal Code) which prohibits non-retroactive (not retroactive) enforcement of the law. While the PTPT Law is applied retroactively (apply retroactively) to terrorism cases that have passed before the emergence of the PTPT Law which regulates it.Such regulation as a consequence that the crime of terrorism is an extraordinary crime (extra ordinary crime), terrorism is international and highly organized, so that many parties become 
victims of the crime who are very professional, hidden, and skilled so that the arrangements and handling are carried out in an extraordinary manner. that is to apply the law retroactively.

The authority of the Police of the Republic of Indonesia concerns its main duties and functions as well as its authority in dealing with and eradicating terrorists with various efforts taken through the application of legal regulations and sanctions in the PTPT Law and Law Number 2 of 2002 concerning the Indonesian National Police. The police in carrying out counter-terrorism efforts move from two policies, namely: penal and non-penal policies. The penal policy is a policy to counter terrorism crimes based on criminal law, so that the police are required to have two main tasks, namely Investigation and Investigation as regulated in the Criminal Procedure Code and the PTPT Law. Non-penal policies (outside criminal law) are countermeasures against criminal acts of terrorism not based on lawcriminal justice by approaching the root cause of the birth of the problem of terrorism from a social point of view. The Anti-Terror Detachment 88 formed by the National Police is optimized as the frontline in conducting intelligence, investigations, prosecutions, and arrests of terrorist network organizations to eradicate all the roots of terrorism in the territory of the Republic of Indonesia, and or make legal efforts, namely confronting terrorist perpetrators against terrorism. in the trial of the criminal justice system.

\section{References}

Abas, Nasir, Eradicating Terrorism, Hunting for Noordin M. Top, Jakarta: Grafindo Khazanah Ilmu, 2009.

Abbas, Ali, Anton, and Arif, TNI-Polri in a Period of Political Change, Bandung: Masters Program in Defense Studies, Bandung Institute of Technology, 2008.

Asmadi, Erwin, Proof of Terrorist Crimes Analysis of Court Decisions in the Robbery Case of the Cimb Niaga Bank Medan, Sofmedia, Medan: 2012.

Garnida, Dadang, Guidelines for the Implementation of the Duties of the National Police in the Field, Jakarta: The Headquarters of the Indonesian National Police, 2005.

Bemmelen, JM, van, Criminal Law I: Material Criminal Law General Section, Translated by Hasan without place: Bina Cipta, 1984.

Hamzah, Andi, Indonesian Criminal Procedure Law, Jakarta: Arikha Media Cipta, 1993.

Harahap, M. Yahya, Discussion of Problems and Application of the Criminal Procedure Code, Jakarta: Sinar Graphic, 2003.

Hatrik, Hamzah, Principles of Corporate Responsibility in Indonesian Criminal Law Strict Liability and Vicarious Liability, Jakarta: Raja Grafindo Persada, 1996.

Big Indonesian Dictionary, "Understanding Authority", Balai Pustaka, Jakarta 3rd Edition, 2003.

Kelana, Momo, Understanding the Police Act, Jakarta: 2002. Kunarto, Police Ethics, Jakarta: PT. Cipta Manunggal, 1997.

M. Top, Noordin, known as the main figure in terrorism, was shot dead on August 8, 2009 by the Special Detachment (Densus) 88 Anti-Terror Police.

M. Hussein, Harun and Hamid, H. Hamrat, Discussion of the problems of the Criminal Procedure Code for Investigation, Jakarta: 1992.

Moeljatno., Principles of Criminal Law, Jakarta: Rineka Cipta, 2002.

Mulyadi, Mahmud, Police in the Criminal Justice System, Medan: Usupress, 2009. 
Munir, Awaiting Anti-Terrorism Policy, Coalition for Civil Safety, Publisher Partial Coalition for Civil Safety, Jakarta, 2003.

Muzadi, Hasyim, “Crimes of Terrorism”, Refika Aditama, Bandung 2004. Nasrullah, T, “At a Glance Juridical Review Both Material and Legal Aspects.

Formal Against Law Number 15 of 2003 concerning Eradication of Criminal Acts of Terrorism".

Priatmodjo, Galih, Densus 88 The Undaercover Squad-Revealing the Anti-Terrorist "Hanut Squad" Elite Unit.

Reksodipputro, Mardjono, Human Rights in the Criminal Justice System, Center for Legal Services and Services, Institute of Criminology, University of Indonesia, Jakarta, 1993, Muladi (1995).

Sabuan, Ansorie, Criminal Procedure Law, Bandung: Angkasa, 1990.

Regards, Moch Faisal, Motivation for acts of terrorism in Jakarta: Mandar Maju, 2005. Sianturi, SR, Principles of Criminal Law in Indonesia and Its Application, Jakarta:

Ahaem Petehaem Alumni, 1989.

Soemitro, Ronny Hanitijo, Legal Research Methodology, Jakarta: Ghalia Indonesia, 1982.

Sunggono, Bambang, Legal Research Methods (An Introduction), Jakarta: PT. Raja Grafindo Persada, 2001.

Yasa Tohjiwa, Gde, Critical Notes, Jakarta, 1995.

General explanation of Law Number 15 of 2003 concerning Eradication of Criminal Acts of Terrorism (UUPTPT).

Moeljatno, the Criminal Code, cet. 21, Jakarta: Earth Literacy, 2001.

Ermansjah Djaja, "Special Criminal Code”, Law of the Republic of Indonesia Number 15 Year 2003, Sinar Graphic, Jakarta 2009.

The provision of punishment for co-administration in Article 57 Paragraph (2) of the Criminal Code does not specify a minimum penalty limit. This is different from Article 13 of the PTPT Law which determines the minimum and maximum limits of punishment.

Solahuddin, Criminal Code and Criminal Procedure Code, Jakarta: Visimedia, 2007.

Since the enactment of the Second Amendment to the 1945 Constitution of the Republic of Indonesia Chapter XII concerning National Defense and Security, MPR RI Decree No. VI/MPR/2000 and MPR RI Decree No. VII/MPR/2000, there has been a constitutional change that confirms the formulation of the duties, functions, and roles of the Indonesian National Police as well as the separation of the Indonesian National Armed Forces and the Indonesian National Police in accordance with their respective roles and functions.

Law Number 2 of 2002 also regulates professional development and professional code of ethics so that the actions of the Indonesian National Police officers can be accounted for, both legally, morally, as well as professionally technically and especially Human Rights.

Government Regulation in Lieu of Law Number 1 of 2002 concerning Eradication of Criminal Acts of Terrorism as promulgated based on Law Number 15 of 2003 (hereinafter referred to as the Terrorism Law), Article 1 Number 1.

UU no. 15 of 2003 concerning Terrorism, Article 25 Paragraph (1). 
KUHAP, Article 184 Paragraph (1).

UU no. 15 of 2003 concerning Terrorism, Article 27 Letter b and c.

Sofyan Nasution, "Efforts to Encourage Government Bureaucracy Based on Good Governance Principles", Paper Presented at a Seminar on Policy Paper Dissemination, held by the National Law Commission of the Republic of Indonesia, October 2, 2003, Medan, pp. 1-5.

http://id.wikipedia.org/wiki/Terrorism. http://budhiachmadi.wordpress.com/2012/10/08/terrorismtraditional-baru-dan-hybrid, accessed 22 April 2003.

http://metrotvnews.com/read/newsvideo/2011/04/15/126356/Bom-Bunuh-Diri-di- Mosque-PolrestaCirebon-Tens-Terluka, accessed on February 24, 2013.

http://koran-jakarta.com/index.php/detail/view0, accessed date 24 February 2013.

http://www.academia.edu/735650/Pengaruh_AIPAC_Terhadap_Kebijakan_Ameri ka_Serikat, accessed on March 23, 2013.

http://www.negara Hukum.com/law/pengertian-keauthoran.html, accessed on April 17, 2003.

http://putranto88.blogspot.com/2011/06/definisi-terrorism.html, accessed on March 10, 2013.

http://wafflox.blogspot.com/2012/02/difference-crime-terrorism-with.html, accessed on March 10, 2013.

http://www.inilah.com/read/detail/416972/danger-terrorism-still-be- threats, accessed 26 April 2013.

http://law.unsrat.ac.id/uu/uu_9_2008.htm, Law of the Republic of Indonesia Number 9 of 2008 concerning the Use of Chemicals and the Prohibition of the Use of Chemicals as Chemical Weapons.

http://wonkdermayu.wordpress.com/Universitas- Hukum/ Hukum-Pidana, accessed on April 25, 2013.

http://www. Hukumonline.com/centerdata/detail/13284/node, Retrieved On March 31, 2013.

http://www.negara Hukum.com/law/pengertian-keauthoran.html, accessed on April 17, 2003.

http://www.polri.go.id/pro/lapor/pages/11, Accessed on March 29, 2013.

http://www.polri.go.id/pro/lapor/pages/12, accessed on March 29, 2013.

http:/ /law.kompasiana.com/2011/02/11/mengatasi-kerasan-penegakan-legalaladensus-88/, accessed on April 4, 2013.

http://clubbing. Kapanlagi.com/threads/70150-Sejarah-Terformasi-Densus-88, accessed on 28 April 2013. 